\title{
COMPETITIVE ADVANTAGE ANALYSIS OF SOYBEAN FARMING IN INDONESIA
}

\section{Bernadeta Julia WijayaPuspita Sari, Sucihatiningsih Dian WisikaPrajanti*}

Economy of Development Studies Faculty, Economic Faculty, Universitas Negeri Semarang

*Corresponding E-mail: dianwisika@yahoo.com

Recieved: March 2016; Accepted: December 2016

\begin{abstract}
Soybean is one of the commodities strategy, because the demand for soy in the international and domestic market has always increased. To fill the domestic soybean demand by importing soybeans. This is a serious problem because it will have an impact on the decline in farm income due to import soybeans. The aim of this study was to determine whether soybean farming in the village Banaran, Pracimantoro, Wonogirihas a competitive advantage and comparative advantage, as well as to determine the impact of government policy on soybean farming. The method used is qualitative method by interviews with soybean farmers. Results of interview with farmers processed by Policy Analysis Matrix (PAM), which produced the analysis forms of competitive advantage, comparative advantage, and the impact of government policy.Results from this study are of soybean farming in the village Banaran, Pracimantoro, Wonogiri only has a competitive advantage.Overall government policies protective of soybean farming in the village Banaran.
\end{abstract}

Keywords: Soybean Farming, Competitive Advantage, Comparative Advantage, The Impact of Government Policy

JEL Classification: O13, Q12, Q13

\section{Introduction}

Soybean is one of the protein resources considered as affordable thus highly favored by the customers. Beside its cheap price, soybean is also quite nutritional. Most households consume soybean in the form oftofu and soybean cake (tempe), therefore, the biggest consumers are from tofu and soybean cake (tempe) industry (Darmadjati andSwastika et al., 2005). This causes soybean becomes one of Indonesian strategic commodities, thus its availability needs to be preserved.

Alongside the increasing number of population, the domestic demands of soybean also have potential to increase as well. The population growth also will affect the demand of food such as tofu, soybean cake (tempe), soy sauce, taucho, etc. (Bayu et al., 2014). Although soybean's availability is preserved, Indonesia is not capable yet to fulfil national demands of soybean (Prajanti, 2012).

Based on domestic production map, Indonesia is very dependable to East Java, Central Java, and Nusa Tenggara Barat (NTB) as the main supplier for soybean (Prajanti, 2014). The rank shows that Central Java comes second after East Java for soybean commodity (Hardiansyah, 2014). In 2014, Central Java reached its peak due to the biggest soybean production of 125.466 quintal. The following table provides information about the harvesting area, production, and productivity of soybean in Central Java as one of soybean suppliers in Indonesia from 2010 - 2014. 
Avalaible online at http://journals.ums.ac.id

Jurnal Ekonomi Pembangunan, 17 (2), December 2016, 143-151

Table 1. Harvesting Area, Production, and Productivity of Soybean in Central Java Year 2010 - 2014

\begin{tabular}{cccc}
\hline Year & $\begin{array}{c}\text { Harvesting } \\
\text { Area (Ha) }\end{array}$ & $\begin{array}{c}\text { Production } \\
\mathbf{( K w )}\end{array}$ & $\begin{array}{c}\text { Productivity } \\
\mathbf{( H a / K w )}\end{array}$ \\
\hline 2010 & 114.070 & 187.992 & 16,48 \\
2011 & 81.988 & 112.273 & 13,69 \\
2012 & 97.112 & 152.416 & 15,69 \\
2013 & 65.278 & 99.318 & 15,21 \\
2014 & 72.235 & 125.466 & 17,37 \\
\hline
\end{tabular}

Source: BadanPusatStatistik, Jawa Tengah 2015

Central Java is one of the biggest suppliers for soybean in Indonesia, moreover, Central Java has quality and quantity aspects of it soybean product in Grobogan. Nevertheless, the local availability of soybean in Central Java is still not adequate yet to be depended on if the society only relies on soybean production in Grobogan only (Revian, 2015). On the other hand, Wonogiri's soybean product also has a big potential to be developed. The following table shows the harvesting area, production, and productivity of soybean in Wonogiri from 2010 - 2014.

Table 2. Harvesting Area, Production, and Productivity of Soybean in Wonogiri Year 2010 - 2014

\begin{tabular}{cccc}
\hline Year & $\begin{array}{c}\text { Harvesting } \\
\text { Area (Ha) }\end{array}$ & $\begin{array}{c}\text { Production } \\
\text { (Kw) }\end{array}$ & $\begin{array}{c}\text { Productivity } \\
\text { (Kg/Ha) }\end{array}$ \\
\hline 2010 & 25.948 & 39.570 & 15,25 \\
2011 & 18.718 & 22.475 & 12,01 \\
2012 & 16.141 & 19.228 & 11,91 \\
2013 & 14.753 & 21.000 & 14,23 \\
2014 & 9.985 & 14.971 & 14,99 \\
\hline
\end{tabular}

Source: Badan Pusat Statistik Kabupaten Wonogiri 2011-2015.

Government's efforts to improve soybean production in Wonogiri are not only focused on the expansion of lands but also the distribution of subsidized fertilizer. The fertilizer subsidy is aimed to reduce the cost that needs to be spent by farmers in producing soybean. Recently, people are facing the fluctuated price of soybean, especially since the price is rising very sharply, which causes tofu and soybean cake (tempe) cannot run their business for their basic ingredient is considered very expensive (Prajanti and Soesilowati, 2012) (Wahyuni, 2013).

One of the vilages in Wonogiri that is benefitting from fertilizer subsidy is Banaran, Pracimantoro which has higher harvesting area, production, and productivity than other villages. However, soybean is now replaced by the tobacco plantation since it is believed to gain more profit than soybean. Tobacco farming contributes around $60-80 \%$ towards farmers' income in Wonogiri. The use of best quality fertilizer will affect the quality of soybean produced and minimalize the production cost. Therefore, the government policy such as fertilizer subsidy that is conducted to help farmers from Wonogiri will reach maximum results.

The aim of this research is to know the competitive advantage of soybean farming. According to Nardi\& Todd (2007), Zimmer (2010), Liu \&Revell (2009), competitive advantage in 


\section{Jurnal Ekonomi Pembangunan, 17 (2), December 2016, 143-151}

a commodity market reflects many factors such as comparative and competitive. This research is aimed to reveal the agriculture economic

\section{Research Methodology}

\subsection{Methodology in Deciding Research Area}
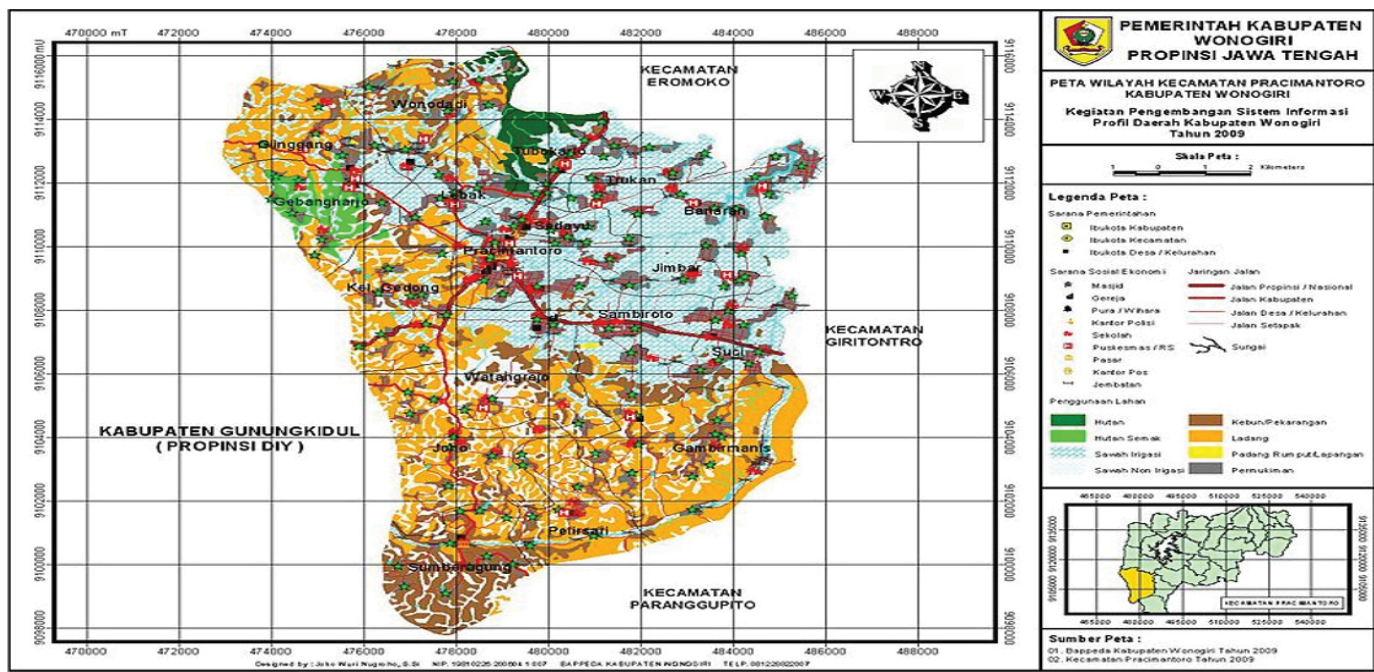

Figure 1. The Map of Banaran Village, Pracimantoro, Wonogiri

Source: BAPPEDA Kab. Wonogiri 2009

The research was conducted in Wonogiri, in which the soybean farming is located in Banaran village, Pracimantoro, Wonogiri. The location is the central of soybean production in Wonogiri based on the area, production, and productivity..

\subsection{Types and Sources of Data}

This research employs primary and secondary data. The primary data is collected directly from interview technique to the leader of farmers union in eight villages in Banaran, Pracimantoro, Wonogiri, Cental Java. The secondary data in this research is collected through statistic center Badan Pusat Statistik (BPS) of Central Java, BPS of Wonogiri, and Dinas Pertanian Tanaman Pangan Provinsi Jawa Tengah.

\subsection{Research Variable}

The research variable of this research consists of primary data and secondary data. The primary data that is required in this research is input structure (tradable input and domestic factor) and private price (tradable input, domestic factor price, and output price within farmers' level). The secondary data that is required in this research is the development of harvesting area, production, and productivity, production development, consumption and world soybean price, development of the exchange rate of US dollar to rupiah, actual market price conversion factor (private) to predicted price (social), and the development of market price and also the import price of chemical fertilizer.

\subsection{Data Analysis Method}

The data analysis in this research employs PAM method (policy Analysis Matrix). Pam can be employed to measure the coefficient of competitive advantage and comparative advantage, the profit level in financial and economic value of soybean farming, government policy also can be measured as a whole and systematically. Comparative advantage is a concept developed by David Ricardo to explain the allocation efficiency of 
Avalaible online at http://journals.ums.ac.id

\section{Jurnal Ekonomi Pembangunan, 17 (2), December 2016, 143-151}

open resources (Koo and Kennedy, 2005). PAM provides framework that enables to measure the index of comparative advantage, protection coefficient, and competitive advantage index simultaneously as well as to analyze government policy (Najarzadeh et al, 2011).

Table 3. Policy Analysis Matrix (PAM)

\begin{tabular}{|c|c|c|c|c|}
\hline & \multirow[b]{2}{*}{ Income } & \multicolumn{2}{|c|}{ Cost } & \multirow[b]{2}{*}{ Profit } \\
\hline & & $\begin{array}{c}\text { Tradable } \\
\text { Input }\end{array}$ & $\begin{array}{c}\text { Domestic } \\
\text { Factor }\end{array}$ & \\
\hline \multicolumn{5}{|c|}{ Social Price (Efficiency Price) } \\
\hline Private & $\mathrm{A}$ & $\mathrm{B}$ & $\mathrm{C}$ & $\mathrm{D}=\mathrm{A}-\mathrm{B}-\mathrm{C}$ \\
\hline Social & $\mathrm{E}$ & $\mathrm{F}$ & $\mathrm{G}$ & $\mathrm{H}=\mathrm{E}-\mathrm{F}-\mathrm{G}$ \\
\hline $\begin{array}{l}\text { Divergent } \\
\text { effect }\end{array}$ & $\mathrm{I}=\mathrm{A}-\mathrm{E}$ & $\mathrm{J}=\mathrm{B}-\mathrm{F}$ & $\mathrm{K}=\mathrm{C}-\mathrm{G}$ & $\begin{array}{c}\mathrm{L}=\mathrm{D}-\mathrm{H}= \\
\text { I-J-K }\end{array}$ \\
\hline
\end{tabular}

Source: Scoot Pearson (2005)

Details:

$\mathrm{A}=$ The acceptance of farming to private price

$\mathrm{B}=$ Total tradable input price of farming to private price

$\mathrm{C}=$ Total non-tradable input price of farming to private price

$\mathrm{D}=$ Private profit

$\mathrm{E}=$ The acceptance of farming to social price

$\mathrm{F}=$ Total tradable input price of farming to social price

$\mathrm{G}=$ Total non-tradable input price of farming to social price

$\mathrm{H}=$ Social profit

$\mathrm{I}=$ Transfer output (TO)

$\mathrm{J}=$ Transfer Input (IT)

$\mathrm{K}=$ Transfer Factor $(\mathrm{TG})$

$\mathrm{L}=$ Net transfer (NT)

The indicators of PAM include, (1) Private Profit (PP) = A-B-C; (2) Social Profit (SP) = E-F-G; (3) Private Cost Ratio (PCR) $=$ C/A-B; (4) Domestic Ratio Cost (DRC) $=$ G/E-F; (5) Transfer Output (TO) = A-E; (6) Nominal Protection Coefficient Output $(\mathrm{NPCO})=\mathrm{A} / \mathrm{E} ;(7)$ Transfer Input (TI) = B-F; (8) Nominal Protection Coefficient Input $(\mathrm{NPCI})=\mathrm{B} / \mathrm{F}$; $(9)$ Transfer Factor $(\mathrm{TF})=\mathrm{C}$-G; (100 Effective Protection Coefficient (EPC) = A-B/E-F; (11) Net Transfer (NT) D-H; (12) Profit Coefficient $(\mathrm{KK})=\mathrm{D}-\mathrm{H}$; (13) Subsidy Ration for Producer (SRP) L/E (Faroby et al 2008).
Mobasser et al (2012) stated that PAM consists of two equation which are matrix from the first row which shows income, cost and benefit from the private price and matrix from the second row calculates the same from the first row based on predicted price (social price). There are there important issues from PAM that can be discussed (1) the impacts of government policy toward the competitive advantage and farming profit; (2) the impacts of investment policy towards the efficiency level of economy and comparative advantage, and (3) the impacts of agriculture researchers policy toward the development of technology (Rachman et al., 2004).

\section{Result and Discussion}

\subsection{Analysis of Competitive Advantage and Comparative Advantage}

The PAM of soybean farming in Banaran village, Pracimantoro, Wonogiri results in private and social indicator; and competitive and comparative advantage indicator as follow to measure the financial advisability, the level of price used is the private price, which is the real price paid by farmers, on the other hand, to measure the economic advisability, the social price or predicted price, is used Soetriono, 2006). 
Avalaible online at http://journals.ums.ac.id

Jurnal Ekonomi Pembangunan, 17 (2), December 2016, 143-151

Table 4. Policy Analysis Matrix Soybean Farming in Banaran Village

\begin{tabular}{lcccc}
\hline & \multirow{2}{*}{ Income } & \multicolumn{2}{c}{ Cost } & \multirow{2}{*}{ Profit } \\
\cline { 3 - 4 } & & $\begin{array}{c}\text { Tradable } \\
\text { Input }\end{array}$ & $\begin{array}{c}\text { Domestic } \\
\text { Factor }\end{array}$ & \\
\hline Private & 9.977 .500 & 1.640 .000 & 7.020 .002 & 1.317 .498 \\
Social & 9.434 .110 & 2.050 .550 & 7.990 .002 & -606.442 \\
Divergent Effect & 543.390 & -410.550 & -970.000 & 1.923 .940 \\
\hline
\end{tabular}

Source: Primary Data, Processed in 2015

\subsection{Competitive Advantage Analysis}

Table 5. Financial Profit of Soybean Farming in Banaran Village

\begin{tabular}{clc}
\hline No. & \multicolumn{1}{c}{ Details } & Calculation \\
\hline 1. & Total Income & 9.977 .500 \\
2. & Total Cost & 8.660 .002 \\
3. & Privat Profitability & 1.317 .498 \\
4. & Privat Cost Ratio & 0.84197925 \\
\hline
\end{tabular}

Source: Primary Data, Processed in 2015

The analysis of competitive advantage can be calculated using Private Probability (PP) or Financial Advantage and Private Cost Ratio (PCR). Private Probability (PP) is the deviation between the income and the real cost paid by farmers, and Private Cost Ratio (PCR) is the ratio between factor domestic cost and output plus value from input cost traded in private cost. If Private Probability (PP) value is more than 0 $(\mathrm{PP}>0)$, it is considered the farming has financial profit economically or can be concluded that the commodity has competitive advantage. On the contrary, if the value of Private Probability is less than $0(\mathrm{PP}<0)$, it can be concluded that the farming does not have financial profit or the commodity does not have competitive advantage.If the value of Private Cost Ratio (PCR) is more than 1 (PCR $>1$ ), the farming activity is financially profitable or has competitive advantage when government policy is available. However, if the Private Cost Ratio (PCR) is less than 1 (PCR $<1$ ), the farming activity is not financially profitable or does not have competitive advantage.

PAM analysis shows Private Profitability (PP) of soybean farming as Rp. 1.317.498,00 per hectare. It shows that financially, soybean farming activity can be proceeded since it has profit by the subsidy policy from government. Beside financial profit, competitive advantage of soybean farming also can be seen from the efficiency analysis that is measured by Private Cost Ratio (PCR). PCR for soybean farming is 0,84 which indicates that soybean farming in Banaran has competitive advantage.

The comparative advantage analysis can be measured by economic profit or Social Profitability (SP) and Domestic Resource Cost (DRC). Social Profitability (SP) is the deviation between the income and cost measured with social cost, and Domestic Resource Cost (DRC) is a ratio input cost, which cannot be traded with the plus value of output from input cost traded in economic price. If the value of Social Profitability (SP) is more than 0 ( $\mathrm{SP}>0$ ) the commodity is economically profitable and has comparative advantage. On the other hand, if the value of Social Profitability (SP) is less than 0 , it means that the commodity is not economically profitable and does not have comparative advantage. The value of Domestic Resource Cost (DRC) that is less than $1(\mathrm{DRC}<1)$ shows that a commodity is efficient economically or has competitive advantage without the 
Avalaible online at http://journals.ums.ac.id

Jurnal Ekonomi Pembangunan, 17 (2), December 2016, 143-151

intervention of government policy and if the Domestic Resource Cost (DRC) is more than economically and does not have competitive 1 , it means that a commodity is not efficient advantage.

\subsection{Comparative Advantage Analysis}

Table 6. Economic Profit of Soybean Farming in Banaran Village

\begin{tabular}{clc}
\hline No. & \multicolumn{1}{c}{ Details } & Calculation \\
\hline 1. & Total Income & 9.434 .110 \\
2. & Total Cost & 10.040 .552 \\
3. & Social Profitability & -606.442 \\
4. & Domestic Resource Cost & 1.082134092 \\
\hline \multicolumn{2}{c}{ Source: Primary Data, Processed in 2015}
\end{tabular}

PAM shows Social Profitability (SP) of soybean farming as negative Rp. 606.44200 per hectare. It shows that economically, soybean farming activity does not have profit within perfect market competition condition. Beside economic profit, the comparative advantage of soybean farming also can be seen by economic efficiency measured by Domestic Resource Cost (DRC). The DRC of soybean farming is 1,08 . The DRC value which si more than one indicates that soybean farming in Banaran does not have comparative advantage.

\subsection{Efficiency Analysis}

A commodity can be considered financially efficient if the Private Cost Ratio (PCR) is less than $1(\mathrm{PCR}<1)$, and a commodity can be considered economically efficient if the value of Domestic Resource Cost (DRC) is less than 1 $(\mathrm{DRC}<1)$. The value of PCR is 0,84 and the DRC is 1,08 in soybean farming.

The value of Private Cost Ratio (PCR) and Domestic Resource Cost (DRC) in soybean farming shows that the value of Private Cost Ratio $(\mathrm{PCR})$ is less than $1(\mathrm{PCR}<1)$ and the value of Domestic Resource Cost (DRC) is less than 1 $(\mathrm{DRC}>1)$, it can be written that PCR $<1>$ DRC. Therefore, soybean farming in Banran village is financially efficient and not economically efficient. The value of Private Cost Ratio (PCR) in soybean farming has lesser value than the Domestic Cost
Ratio (DRC) or PCR $<$ DRC). It indicates that government policy supports soybean farming which resulting to the improvement in production efficiency.

\subsection{Analysis of the Impacts of Government Policy}

Government policy towards soybean farming can be analyzed through output policy, input policy, and input-output policy as follow:

Table 7

The Impacts of Government Policy towards Soybean Farming in Banaran Village

\begin{tabular}{clc}
\hline No. & \multicolumn{1}{c}{ Details } & Value \\
\hline 1. & Transfer Output (TO) & 543390 \\
2. & Transfer Input (TI) & -410550 \\
3. & Transfer Factor (TF) & -970000 \\
4. & Net Transfer (NT) & 1923940 \\
5. & Nominal Protection & \\
& Coefficient On Tradable & 1.057598438 \\
& Outputs (NPCO) & \\
6. & Nominal Protection & 0.799785423 \\
& Coefficient On Tradable & \\
7. & Inputs (NPCI) & Effective Protection \\
& Coefficent (EPC) & 1.12919784 \\
8. & Profitability Coeficient (PC) & -2.172504543 \\
9. & Subsidy Ratio to Producers & 0.203934446 \\
& (SRP) & \\
\hline
\end{tabular}

Source: Primary Data, Processed in 2015 


\section{Jurnal Ekonomi Pembangunan, 17 (2), December 2016, 143-151}

Government policy towards soybean farming can be seen from the indicators measured by the components in Table 7 as follow:

1. Output Policy

The ratio is used to measure Transfer Output (TO and Nominal Protection Coefficient on Tradable Outputs (NPCO). Nominal Protection Coefficient on Tradable Outputs (NPCO) is the ratio between the income measured based on the private price and the income measured by the social price. Nominal Protection Coefficient on Tradable Outputs (NPCO) is used to see whether particular commodity receive protection from the government or not. Nominal Protection Coefficient on Tradable Outputs (NPCO) value of more than $1(\mathrm{NPCO}>1)$ shows that there is a government policy causes the private price output bigger than the social price output. If the value of Nominal Protection Coefficient on Tradable Outputs (NPCO) is less than 1 (NPCO $<1)$, it shows that there is no government policy that causes the private price output lower than social price output. The value of Transfer Output (TO) is more than 0 shows that there is transfer output from consumer to producer (farmers). If the value of Transfer Output (TO) is less than 0, it shows that there is no transfer output from consumer to producer (farmers).

Transfer Output (TO) is equal to Rp. 543.390 and the Nominal Protection Coefficient on Tradable Outputs (NPCO) is equal to 1,06 shows that the value of Transfer Output (TO) is positive while the value of Nominal Protection Coefficient on Tradable Outputs (NPCO) is more than 1. It indicates that soybean farming has benefitted in terms of protection output from government. This condition is similar with the research done by Rori (2011) for coconut commodity where coconut producers get protection for price with the government policy, which secures the price received by farmers to be higher than its predicted price.

2. Input Policy

The input policy is a government policy that affects the input production of agriculture, such as fertilizer subsidy. Soybean farming policy towards the input can be analyzed through the indicator of Transfer Input (TI), Nominal Protection Coefficient on Input (NPCI), and Transfer Factor (TF). The greater the impacts of government policy toward the input can be measured from Nominal Protection Coefficient on Input (NPCI). Nominal Protection Coefficient on Input (NPCI) of more than 1 (NPCI $>1$ ) shows that the government policy causes one particular commodity to pay tradable input higher than the price in international market. Nevertheless, in which if the Nominal Protection Coefficient on Input (NPCI) is less than $1(\mathrm{NPCI}<1)$, thus it can be concluded that the domestic price is lower than the international market price.

If the value of Transfer Input (TI) is more than 0 (TI $>0$ ), it shows that there is a transfer from farmers to producer input tradable, and if the value of Transfer Input (TI) is less than 0 (TI < 0 ), it shows that there is no transfer from farmers to producer input tradable. Transfer Factor (TF) appears as the impacts of market failure. If the value of Transfer Factor (TF) is more than 0 (TF > 0 ) thus there is transfer from farmers to producer input tradable, and if the value of Transfer Factor (TF) is more than $0(\mathrm{TF}<0)$ thus there is no transfer from farmers to producer input tradable.

The value of Transfer Input (TI) of soybean farming is negative which is $\mathrm{Rp}$. $410.550,00$, while the PCI value of soybean farming is 0,79 , and the value of TF is Rp. 970.000,00. It indicates that the value of TI is less than 0 (TI $<1)$, NPCI is less than 1 (NPCI <1), the value shows that government subsidy in input sector has already been effective since farmers pays tradable input lower than the real price. It also shows that government policy has successfully benefitting farmers.

3. Input-Output Policy

The input-output policy is aimed to see the combine impacts between input and output policy. The policy of input-output can be analyzed using Net Transfer (NT), Effective Protection Coefficient (EPC), Profitability Coefficient (PC), and Subsidy Ratio to Producers (SRP). 


\section{Jurnal Ekonomi Pembangunan, 17 (2), December 2016, 143-151}

If the value of Net Transfer (NT) is more than $0(\mathrm{NT}>0)$, thus it shows that one particular commodity has plus value of profit for producer due to the availability of government policy toward input and output. However, if the value of Net Transfer $(\mathrm{NT})$ is less than $0(\mathrm{NT}<0)$, it can be concluded that there has no plus value of profit due to the availability of government policy toward input and output, thus it shows that the policy is not seen to beneficial for the producer. Effective Protection Coefficient (EPC) is the illustration on how further is the government policy protects or restrains domestic production in the effective way. The goal of Effective Protection Coefficient (EPC0 is to show the impact of mixed transfer caused by one policy (policy transfer0, either transfer of tradable output or transfer of tradable input. The value of Effective Protection Coefficient (EPC) of more than 1 (EPC $>10$ means that the government policy is considered protective, the bigger the value of Effective Protection Coefficient (EPC) the higher the protection by the government. Nevertheless, if the value of Effective Protection Coefficient (EPC) is less than $1(\mathrm{EPC}<10)$, it shows that the government policy is not protective.

The NT value is $\mathrm{Rp}$. 1.923 .940 also positive and the EPC value is 1,13 which is more than 1. The value indicates that government policy toward input-output for soybean farming has run effectively and has given economic incentive to increase production. The PC value of $-2,17$ is affecting on the social profit decrease. Overall, government policy does not give incentive towards social price and the value shows that PC causes the decrease of social price. The SRP value of 0,20 means positive value, which also shows that government policy that is currently on going makes farmers spend smaller production cost. The government policy gives positive effect since it is beneficial for soybean farmers. Government intervention in the form of policy holds a very important role in fulfilling the comparative advantage and competitive advantage of one commodity system (Siregar and Sumaryanto, 2003).

\section{Conclusion}

Soybean farming in Banaran, Pracimantoro, Wonogiri has competitive advantage proven by the result of PP equal to Rp. 1.317.498,00 per hectare and also proven by the value of PCR of 0,84 . Overall, soybean farming is profitable for farmers and financially efficient. Soybean farming only has competitive advantage since the result of $\mathrm{SP}$ is negative and the value of DRC is more than 1. It shows that soybean farming does not have comparative advantage. Soybean farming has competitive advantage because of the availability of government policy. The government policy that is beneficial for farmers can be proven by the result of $\mathrm{NPCO}>1$. TO $>0$, which indicates that soybean farming has benefitted from protection or output protection from government. The result of TI, NPCI, and TF analysis of less than Ofrom government subsidy in input sector has been seen to be effective in which it is beneficial for the government as well.

\section{Acknowledgement}

An utmost gratitude and appreciation is given to UNIVERSITAS NEGERI SEMARANG that has given the author an opportunity to accomplish this research.

\section{References}

Faroby et al, 2008. Analisis Keunggulan Komparatif dan Kompetitif Pengusaha Komoditi Jagung di Kabupaten Grobogan (Studi Kasus: Desa Panunggalan, Kecamatan Pulokulon, Kabupaten Grobogan, Jawa Tengah). Jurnal Agribisnis dan Ekonomi Pertanian (Volume 2. No 1-Juni 2008).

Bayu. R. P, and Hardiansyah N. S. 2014. Strategi Pengembangan Usahatani Kedelai Untuk Mewujudkan Ketahanan Pangan Indonesia. JEJAK: Journal of Economics and Policy. Vol. 7 No. 2 Hal. 184-193.

BPS (BadanPusatStatistik). 2015. Jawa tengah Dalam Angka Tahun 2015. BPS Provinsi Jawa Tengah. 


\section{Jurnal Ekonomi Pembangunan, 17 (2), December 2016, 143-151}

BPS (Badan Pusat Statistik). 2015. Kabupaten Wonogiri Dalam Angka 2015. Wonogiri: BPS Wonogiri.

Darmadjati, D. S., Marwoto, DKS. Swastika, D. M. Arsyaddan Y. Hilman. 2005. Prospek dan Arah Penggembangan Agribisnis Kedelai. Badan Litbang Pertanian. Departmen Pertanian. Jakarta.

Hardiansyah, N. S. 2014. Pengembangan Usahatani Kedelai di Kabupaten Grobogan Sebagai Upaya Mewujudkan Ketahanan Pangan Nasional. Economics Development Analysis Journal. Vol. 3 No. 2.

Koo, W. W. and P. L. Kennedy. 2005. International Trade and Agriculture. Blackwell Publishing.

Liu, Xue.,\& Brian J. Revell. 2009. Competitiveness Change in China's Quality Vegetable Export Post-WTO. Journal of Chinese Economics and Foreign Trade Studies, Volume: 2 Issue: 2.

Nardi, Matias G., \& Todd D. Davis. 2007. Soybean Landed Cost Competitiveness Analysis for Argentina, Brazil, and the United States. VI International PENSA Converence October, 24-26 $6^{\text {th }}, 2007$.

Mobasser, H. R., F. Rastegaripour, and A. Tavassoli. 2012. Study of Effects of Policy Analysis Matrix and Relative Advantage of Rapeseed Production (Case study: Sistan Region). International Journal of Agriculture and Crop Sciences 4 (19): 1421-1425.

Najarzadeh, R., M. Rezagholzadeh, S. Saghaian, M. Reed, and M. Aghare. 2011. The Impact of Trade Liberalization on Persain Rugs: A Policy Analysis Matrix Approach. Journal of Food Distribution Research 42 (1): 91-95.

Rachman, H. P. S., Supriyati, Saptana, and B. Rachman. 2004. Efisiensi dan Daya Saing Sistem Usahatani Beberapa Komoditas Pertanian di Lahan Sawah. Pusat Penelitian dan Pengembangan Sosial Ekonomi Pertanian. Departmen Pertanian. pp. 50-90.
Revian Adhiaksa. 2015. Perencanaan Pengembangan Komoditas Kedelai Dalam Upaya Pemenuhan Kedelai di Kabupaten Wonogiri. Economics Development Analysis Journal.

Rori, Y. P. I. 2011. Analisis Keunggulan Komparatif Usahatani Kelapa menggunakan Policy Analysis Matrix (PAM) di Sulawesi Utara. Pacific Journal 3(6): 1251-1256.

Siregar, M. and Sumaryanto. 2003. Analisis Daya Saing Usahatani Kedelai di DAS Brantas. Jurnal Agro Ekonomi 21 (1): 50-71.

Soetriono. 2006. Daya Saing Dalam TinjuanAnalisis. Penerbit Bayu Media. Malang.

Pearson, Scott R, et al. 2005. Aplikasi Policy Analysis Matrix Pada Pertanian Indonesia. Yayasan Obor Indonesia. Jakarta

Prajanti, Sucihatiningsih Dian Wisika. Soesilowati, Etty. 2012. The Policy Effectiveness of "Go Organic": A Study on Implementation and Efficiency of Organic Vegetable Cultivation in Semarang Municipality. Sosiology Study. Vol. 2 No. 6.

Prajanti, Sucihatiningsih Dian Wisika. 2014. Strategy for controlling agricultural land conversion of paddy by using analytical hierarchy process in Central Java. Management of Environmental Quality: An International Journal. Vol 25. No. 5

-.-.-.. 2012. The Analysis Of Farming Efficiency And Agricultural Extension Performance in Central Java. Economic Journal of Emerging Markets. Vol. 4 No. 1.

Wahyuni. 2013. Daya Saing Kedelai Kecamatan Ganding Kabupaten Sumenep. Jurnal Cemara. Vol. 10 No. 1

Zimmer, Yelto. 2010. Competitiveness of Rapesseed Soybeadns and Palm Oil. Journal of Oilseed Brassica 1(2): July. 